завідувач відділення післядипломної освіти молодших медичних спеціалістів

(КВНЗ "Житомирський медичний інститут" Житомирської обласної ради) ztmedcall@gmail.com

ORCID: 0000-0001-8115-9838

\title{
АКМЕОЛОГІЧНИЙ АСПЕКТ РОЗВИТКУ ПРОФЕСІЙНОЇ МАЙСТЕРНОСТІ СПЕЦІАЛІСТА МЕДСЕСТРИНСТВА ЧЕРЕЗ ПІСЛЯДИПЛОМНУ ОСВІТУ НА ОПОРНИХ ІДЕЯХ в. О. СУХОМЛИНСЬКОГО
}

\section{В статті акцентується увага на пошуку шляхів розвитку професійной майстерності спещіалістів} медсестринства; розглядається проблема післядипломної освіти через акмеологічний аспект; аналізується проблема освіти дорослих, яка базується на основних ідеях та теоретико-методологічних засадах провідних фахівиів педагогіки, медицини, медсестринства; розкривається зв'язок між навчально-виховним процесом курсів підвищення кваліфікації вищих медичних навчальних закладів та педагогічними ідеями В. О. Сухомлинського. Як в свій час, так і сьогодні, вони складають методологічний базис в освітньому процесі крім дошкільних освітніх закладів, загальноосвітніх шкіл, ще й у закладах вищої професійної школи, освіти дорослих. На часі провести паралелі між минулим $i$ сьогоденням, виокремити та застосувати ідеї В. О. Сухомлинського, зберегти і примножити спадщчину великого майстра живого слова, новатора педагогіки та широко застосовувати освітніми закладами

всіх рівнів, включаючи, безперервну освіту впродовж життя фахівців всіх галузей виробництва.

Ключові слова: спеціаліст медсестринства, професійна майстерність, фахова підготовка, післядипломна освіта, педагогіка, акмеологія, педагог-новатор В. О. Сухомлинський.

Постановка проблеми у загальному вигляді та ї̈ зв'язок із важливими науковими чи практичними завданнями. Модернізація безперервної підготовки спеціалістів медсестринства впродовж життя продиктована інтеграційним міжнародним розвитком медичної галузі, впровадженням сучасних інноваційних технологій, зростанням ролі особистості у суспільстві, стрімким підвищенням рівня інтелектуальної праці, інтенсифікації та інформатизації науки і виробництва, що є актуальним при розгляді акмеологічного підгрунтя і визначення ролі спеціаліста медсестринства у реформуванні галузі.

Аналіз останніх досліджень та публікацій. Для вирішення проблеми розвитку медичної галузі необхідні різносторонні важелі впливу, починаючи від реорганізації закладів охорони здоров'я, оснащення сучасною діагностичною апаратурою, інформатизацією та комп'ютерним програмуванням відділень та кабінетів, розробкою стандартів спостереження та догляду за пацієнтами, впровадження протоколів діагностики та лікування. Однак, не менш важливим є підготовка та підвищення кваліфікації кадрового потенціалу, який був би спроможним виконувати завдання, покладені на них 3 надання високоякісних медичних послуг населенню.

Над питаннями реформування медсестринської освіти працювали І. Губенко, О. Горай, С. Гордійчук, В. Коваленко, В. Копетчук, І. Круковська, І. Махновська, С. Поплавська, В. Свиридюк, Т. Чернишенко, 3. Шарлович, В. Шатило, М. Шегедин, Н. Шигонська, П. Яворський.

Безперервна професійна освіта стала предметом дослідження О. Антонової, І. Беха, С. Вітвицької, С. Гончаренка, О. Дубасенюк, В. Іщенко, А. Маркова, Н. Ничкала, Л. Сігаєвої, С. Сисоєвої, 3 Шарлович.

Ідеї теоретико-методологічних аспектів освіти дорослих пропонували у своїх дослідженнях Б. Ананьєв, О. Антонова, С. Вершловський, О. Дубасенюк, Л. Лук'янова, О. Плахотник, Т. Шанскова, 3. Шарлович.

Організовуючи освітній процес курсів підвищення кваліфікації спеціалістів медсестринства передбачає застосування сучасних інноваційних педагогічних технологій під час викладання лекційного матеріалу, на практичних заняттях та урізноманітнити завдання для самостійної аудиторної та позааудиторної роботи слухачів, що сприяє формуванню фахової компетентності і є запорукою розвитку професійної майстерності [1], адже, як зауважував В. Сухомлинський, "в будь-якій справі треба досягати високого ступеня майстерності, бути справжнім художником, творцем" [2: 28].

Впровадження освітнього процесу практикуючих спеціалістів базується, в тому числі, i на фундаментальній науці "акмеологія" (від "асте" - вершина), яка спрямована на вдосконалення людини, за допомогою залучення всіх механізмів педагогічного впливу на формування іiі, як особистості, через самоаналіз, самоорганізацію, самокорекцію, а також самовдосконалення як фахівця з метою покращення результативності в професійній діяльності [3: 11-13].

О. Дубасенюк розділяє твердження Б. Ананьєва, що за допомогою засобів освіти та під іiі впливом відбувається зростання людини через методологічні важелі педагогіки, і, як результат, досягається 
найвищий результат діяльності спеціаліста - "вершину максимальної досконалості", що призводить високого професіоналізму і творчої майстерності фахівця [3: 11-13].

Мета статті в полягає в аналізі наукових джерел дослідників, які прямо або опосередковано торкалися проблем розвитку професійної майстерності, акмеологічних підходів та дослідження творчості В. Сухомлинського.

Відповідно до мети дослідження, нами обумовлено завдання: ознайомившись із матеріалами дослідників, які займатися питаннями, що розкривають суть нашої теми та зупинитися на творчості педагога-новатора В. Сухомлинського, щоб показати багатогранність застосування вченого, які можна застосовувати не тільки в межах загальноосвітньої школи, а й у вищих навчальних закладах.

Виклад основного матеріалу. Вищі медичні навчальні заклади, здійснюючи додипломному підготовку фахівця, його перепідготовку та післядипломну освіту, застосовують продуктивні форми, методи і засоби освітнього процесу, опираючись на сучасні інноваційні технології, використовують досвід передових науковців вищої школи, педагогів-новаторів.

Одним із взірців української педагогіки, що здобув світову славу є Володимир Олександрович Сухомлинський. Для сьогодення науковий здобуток В. Сухомлинського не втратив своєї актуальності i, що важливо, надалі складатиме міцний фундамент, із якого черпатиме його педагогічні ідеї ще не одне покоління педагогів.

М. Вашуленко підкреслює, що "постать В. Сухомлинського сприймаємо як активного співучасника у вирішенні наших сучасних соціально-педагогічних проблем державної ваги, ...який ще тривалий час буде залишатися не тільки нашим сучасником, а й сучасником майбутніх поколінь" [4: 3-5].

Досліджуючи творчість В. Сухомлинського, мимоволі, аналізуєш, порівнюєш, співставляєш, переосмислюєш запропоновані ним педагогічні форми, методи та засоби, що складають доробок педагога-новатора, та, неодмінно, захоплюєшся його неординарністю; сприймаєш як щиру і відкриту світові особистість, мудру і толерантну людину-професіонала.

Для кожного педагога, незалежно від того, де він працює: чи в дошкільному закладі, чи в школі, чи у вищому навчальному закладі, $\epsilon$ що почерпнути із багатої спадщини великого майстра педагогіки. Його праці читають, його ідеями зачаровуються, на його досвіді вчаться, його ідеї запроваджують.

Справді, ідеї В. Сухомлинського корисні не тільки для вчителів, які виховують та навчають дошкільнят та школярів. Вони співзвучні із підготовкою спеціалістів медсестринства, адже професія медичного працівника передбачає наявність цілої низки рис характеру, на вихованні яких акцентує увагу великий педагог, які мають відповідати психограмі медичної сестри, а саме: прояв милосердя, терпимості, терплячості, доброти тощо. Всі ці якості мають базуватися на бажанні безкорисливої допомоги, прояву жертовності, щедрості, толерантності.

Діяльність спеціаліста медсестринства потребує прояву особистісних якостей по відношенню до пацієнта та його родини, що базуються на моральних принципах: честь, сумління, благородство. Моральні цінності закладаються 3 дитинства, однак щоб вони назавжди закріпилися в свідомості спеціаліста медсестринства та використовувалися у побудові взаємин та комунікації, особливий акцент на їх формуванні ставиться у вищому медичному навчальному закладі. В. Сухомлинський наголошував, що не обов'язково голосно говорити "про високі ідеали, нехай ці ідеали живуть в гарячому трепетному серці" [5: 218-225].

С. Світельська-Дірко, досліджуючи творчість В. Сухомлинського, помітила його тезу щодо формування добра в процесі духовної діяльності молодої людини [6: 155], адже, як писав В. Сухомлинський "якщо ти робиш добро, то в основі цієї діяльності повинні бути благородні цілі, задуми" [7: 255-269], а не корисливі помисли.

Еріка Гартманн, аналізуючи спадщину В. Сухомлинського, на основі наведеного визначення поняття "співчуття", з німецького "Психологічного лексикону Гендера" (2007), стверджує, що "співчуття - це ставлення до горя, болю і біди когось іншого як до власних страждань, інстинктивні співстраждання" [8: 32-37]. Якраз медична сестра в процесі своєї діяльності, долучаючись до виявлення проблем пацієнта та пошуку шляхів задоволення його потреб, повинна проявляти якості співчуття, співпереживання, відчуття емпатії.

Г. Васянович， В. Онищенко (2007), досліджуючи утвердження творчості В. Сухомлинського в ноологічних намірах, вважає, що саме О. Сухомлинській "вдалося органічно поєднати в ноологію виділені універсальні цінності людського життя: діяльність, свободу, волю, справедливість, щирість, любов до ближнього, відповідальність, відданість" [9: 11-12].

Учасники освітнього процесу від викладачів до слухачів курсів підвищення кваліфікації, мають постійно працювати над собою, формуючи творчий підхід до розвитку професійної майстерності, а їх "висока педагогічна культура є запорукою успіху" [6: 155].

Педагогічна спадщина В. Сухомлинського розкриває велич новатора-педагога, вчить методиці активного та ефективного виховання у підростаючого покоління цілої низки почуттів: сумління, щиросердності, відповідальності, любові до природи, викликає інтерес до світу прекрасного (естетичні 
почуття); формує навички побудови міжособистісних відносин на принципах людяності, гуманізму та моралі; тісних довірливих сімейних стосунків, що базуються на родинних цінностях, любові до батьків, поваги до старших; збереження фольклору, національних традицій та звичаїв [6: 155].

Медична сестра, що має освітній рівень магістра за спеціальністю "Медсестринство" може бути викладачем вищого медичного навчального закладу і викладати медсестринські дисципліни. Однак, поряд із знаннями з медсестринства, вона повинна володіти знаннями з педагогіки, психології, методики викладання, бездоганно знати і застосовувати сучасні інноваційні форми, методи і засоби навчання та виховання.

А тому, на наш погляд, медична сестра повинна здобути другу вищу педагогічну освіту. Наше припущення базується на тому, що спеціальність викладача вищого навчального закладу у поєднанні 3 професійною медичною освітою має дати кращий продукт освітньої послуги. Наскільки ефективність діяльності залежатиме від здобуття другої вищої освіти і як це вплине на розвиток професійної майстерності викладача медсестринства, нам ще потрібно дослідити.

Проте, незаперечним фактом є те, що навчання впродовж життя повинно стати потребою кожного, щоб забезпечити постійне поповнення багажу знань і затребуваність на ринку надання медсестринських послуг [10], що вимагають майстерного виконання процедур, маніпуляцій, що свідчитиме про вміле поєднання теорії і практики, адже, як стверджував В. Сухомлинський "майстерність рук - це матеріальне втілення в життя допитливого розуму, кмітливості, творчої уваги [11:20].

Висновки. Провівши аналіз ряду наукових надбань 3 педагогіки, включаючи безцінну спадщину В. Сухомлинського, та медсестринства, спостерігаємо тенденцію зв'язку між двома галузями знань, що допоможе у розробці теоретичних і методичних засад щодо розвитку професійної майстерності спеціалістів медсестринства. Людина впродовж життя, як фахівець і особистість, переважну більшість часу відводить на виконання професійних обов'язків. Ось чому стає актуальним навчання дорослої людини впродовж життя, адже післядипломна освіта повинна впливати на розвиток професійної майстерності практикуючих спеціалістів.

Перспективи подальших досліджень потребують необхідності продовжити науковий пошук у педагогічних джерелах та провести експериментальне дослідження 3 метою отримання результати педагогічного експерименту та впровадження результатів дослідження.

\section{СПИСОК ВИКОРИСТАНИХ ДЖЕРЕЛ ТА ЛІТЕРАТУРИ}

1. Шарлович 3. П. Формування професійної майстерності спеціаліста медсестринства через пошуководослідницькі методи організації навчання як компетентнісну складову післядипломної освіти / 3. П. Шарлович // Proceedings of the International Scientific Conference "Topical Issues of Science and Education" (July 17, 2017, Warsaw, Poland). - Vol. 5. - RS Global S. z O. O., Warsaw, Poland, 2017, - C. 99-103. (117 c.)

2. Сухомлинський В. А. Избранные произвидения в 5-ти томах / В. А. Сухомлинський. - К. : Радянська школа, 1980. - T. 2. -28 c.

3. Професійно-педагогічна освіта : акме-синергічний підхід : [монографія] / за ред. О. А. Дубасенюк. Житомир : В-во ЖДУ ім. І. Франка, 2011. - 389 с.

4. Вашуленко М. літературна творчість В. О. Сухомлинського в нових підручниках для початкової школи / М. Вашуленко // Початкова школа. - 2003. - № 9. - С. 3-5.

5. Сухомлинський В. О. Біля джерел життєвого ідеалу / В. О. Сухомлинський // Вибрані твори. В 5-ти томах. К. : Радянська школа, 1977. - Т. 2. - С. 218-225.

6. Світельська-Дірко С. В. Виховання цілісної орієнтації молодших школярів засобами казки в педагогічній спадщині В. О. Сухомлинського : дис.. ... канд. пед. наук : $13.00 .01 /$ СвітельськаДірко Світлана Володимирівна. - Житомир : Житомирський державний університет мені Івана Франка, 2017. $-228 \mathrm{c}$.

7. Сухомлинський В. О. Щоб душа не була пустою / В. О. Сухомлинський // Вибрані твори. В 5-ти томах. - К. : Радянська школа, 1977. - Т. 5. - С. 255-269.

8. Гартманн Е. В. О. Сухомлинський : критик радянської та капіталістичної системи. Новий погляд на спадщину класика педагогіки. / Е. Гартманн // Науково-методичний журнал Шлях освіти. - № 1 (55). - К. : Вид-во "Педагогічна преса", 2010. - С. 32-37.

9. Васянович Г. О. Ноологія особистості : [навчальний посібник для студентів та викладачів] / Г. Васянович, В. Онищенко. - Львів, "Сполом", 2007. -217 с. (С. 11-12).

10. Sharlovych Zoia Andragogical Aspects of Postgraduate Education of Nurse Specialist / Zoia Sharlovych // Proceedings of the III International Scientific and Practical Conference "The Top Actual Researches in Modern Science" (July 31, 2017, Ajman, UAE) / International Scientific and Practical Conference "WORLD SCIENCE" № 8 (24), Vol. 4, August 2017. - С. 18-20.

11. Сухомлинський В. А. Сердце отдаю детям / В. А. Сухомлинський. - Изд. 2-е. - К. : Радянська школа, 1971. $244 \mathrm{c}$.

\section{REFERENCES (TRASLATED \& TRANSLITERATED)}

12. Sharlovych Z. P. Formuvannia profesiinoi maisternosti spetsialista medsestrynstva cherez poshukovo-doslidnytski metody orhanizatsii navchannia yak kompetentnisnu skladovu pisliadyplomnoi osvity [Formation of Nursing 
Specialist's Professional Skills in Terms of Researching Methods of Studies Education as Competence-Based Constituent of Postgraduate Education] / Z. P. Sharlovych // Proceedings of the International Scientific Conference "Topical Issues of Science and Education" (July 17, 2017, Warsaw, Poland). - Vol. 5. - RS Global S. z O.O., Warsaw, Poland, 2017. - $117 \mathrm{~s}$.

13. Sukhomlynskyi V. A. Izbrannyie proizvydeniia v 5-ty tomakh [Selected Works in 5 Volumes]. - K. : Radians'ka shkola, 1980. - T. 2. $-28 \mathrm{~s}$.

14. Dubaseniuk O. A. Profesiino-pedahohichna osvita : akme-synerhichnyi pidkhid [Professional Pedagogical Education : Acme-Synergic Approach] : [monohrafiia] / za red. O. A. Dubaseniuk. - Zhytomyr : V-vo ZhDU im. I. Franka, 2011. $-389 \mathrm{~s}$.

15. Vashulenko M. Literaturna tvorchist V. O. Sukhomlyns'koho v novykh pidruchnykakh dlia pochatkovoi shkoly [Creative Writings of V. O. Sukhomlynsky in New Textbooks for Primary School] / M. Vashulenko // Pochatkova shkola [Primary School]. - 2003. - № 9. - S. 3-5.

16. Sukhomlynskyi V. O. Bilia dzherel zhyttievoho idealu [Near the Source of Perfection] / V. O. Sukhomlynskyi // Vybrani tvory. V 5-ty tomakh [Selected Works in 5 Volumes]. - K. : Radians'ka shkola, 1977. - T. 2. - S. $218-225$.

17. Svitelska-Dirko S. V. Vykhovannia tsilisnoi oriientatsii molodshykh shkoliariv zasobamy kazky v pedahohichnii spadshchyni V. O. Sukhomlynskoho [The Upbringing of Value Orientations in the Schoolchildren of Primary Schools by Means of Fairy-Tales in Pedagogical Legacy of V. O. Sukhomlynsky] : dys..kand. ped. nauk : $13.00 .01 /$ Svitelska-Dirko Svitlana Volodymyrivna. - Zhytomyr : Zhytomyrskyi derzhavnyi universytet meni Ivana Franka, 2017. $-228 \mathrm{~s}$.

18. Sukhomlynskyi V. O. Shchob dusha ne bula pustoiu [The Soul Shoudn't Be Empty]/ V. O. Sukhomlynskyi // Vybrani tvory. V 5-ty tomakh [Selected Works in 5 Volumes]. - K. : Radians'ka shkola, 1977. - T. 5. - S. 255-269.

19. Hartmann E. V. O. Sukhomlynskyi : krytyk radians'koi ta kapitalistychnoi systemy. Novyi pohliad na spadshchynu klasyka pedahohiky [V. O. Sukhomlynsky is a Critic of Soviet Capitalist System. A New Perspective on a Classic Pedagogy] / E. Hartmann // Naukovo-metodychnyi zhurnal Shliakh osvity [The Methodological Journal "Way of Education"]. - № 1 (55). - K. : Vyd-vo "Pedahohichna presa", 2010. - S. 32-37.

20. Vasianovych H. O. Noolohiia osobystosti [Noology of the Personality] : [navchalnyi posibnyk dlia studentiv ta vykladachiv] / H. Vasianovych, V. Onyshchenko. - Lviv, "Spolom", 2007. -217s.

21. Sharlovych Zoia Andragogical Aspects of Postgraduate Education of Nurse specialist / Zoia Sharlovych // Proceedings of the III International Scientific and Practical Conference "The Top Actual Researches in Modern Science" (July 31, 2017, Ajman, UAE) / International Scientific and Practical Conference "WORLD SCIENCE" № 8 (24), Vol. 4, August 2017. - C. 18-20.

22. Sukhomlynskyi V. A. Serdtse otdaiu detiam [My Heart I Give to Children]. - Izd. 2-e. - K. : Radians'ka shkola, 1971. $-244 \mathrm{~s}$

\section{Шарлович 3. П. Акмеологический аспект развития профессионального мастерства специалиста медсестринства через последипломное образованиее на опорных идеях В. А. Сухомлинского.}

В статье акцентируется внимание на поисках путей развития профессионального мастерства специалиста медсестринства; рассматривается проблема последипломного образования через акмеологический аспект; анализируется проблема образования взросльх, которая базируется на основных идеях и теоретико-методологических принципах ведущих деятелей педагогики, медицинь, медсестринства; раскрывается связь между учебно-воспитательным прочессом курсов повышения квалификации выстих медицинских учебных заведений и педагогическими идеями В. А. Сухомлинского. Как в свое время, так и сегодня, они составляют методологический базис в образовательном прочессе кроме дошкольных образовательных заведений, общеобразовательных школ, еще и в заведениях высшей профессиональной школь, образования взросльх. Актуальным есть сегодня провести параллели между прошлым и настоящим, вычленить и применить идеи В. А. Сухомлинского, сберечь и приумножить

наследие великого мастера живого слова, новатора педагогики и широко применить учебными заведениями всех уровней, включая, непрерывное образование на протяжении жизни специалистов всех отраслей производства.

Ключевые слова: специалист медсестринства, профессиональное мастерство, профессиональная подготовка, последипломное образование, педагогика, акмеология, педагог-новатор В. А. Сухомлинский.

\section{Sharlovych Z. P. The Acmeological Aspect of Professional Skills Development of a Medical Specialist through the Basis of Postgraduate Education Ideas of V. O. Sukhomlynsky.}

The article focuses on finding ways to develop the professional skills of a nurse specialist; the issue of postgraduate education is considered through the prism of acmeological aspect; the issue of adult education, which is based on the major ideas, theoretical and methodological principles of leading specialists in pedagogy, medicine and nursing, is analyzed; the connection between the educational process of higher education courses

of higher medical educational institutions and pedagogical ideas of V. O. Sukhomlynsky is revealed. The problem of training the nurses' specialists is revealed in accordance to a new vision within the requirements of medical sector reformation. At the forefront, apart from having professional knowledge, are being placed the 
ability to carry out patient care and skills in the implementation of manipulations and procedures, as well as their ability to autonomy in decision-making, efficiency and mobility, together with the ability to search and accumulate information; independent search for sources for self-education and constant desire for knowledge and its replenishment. The connection of theory and practice will ensure the introduction of the knowledge gained into practical health care effort. Medical specialists should be trained by tutors not only highly qualified in medicine and clinical nursing, but also possessing a high level of pedagogical knowledge, together with being competent in methodology of teaching, didactics, education; their successful implementation in the educational process will ensure retraining and professional development of future specialists. V. O. Sukhomlynsky's works together with his scientific and pedagogical heritage serve the best example of its effectiveness. Nowadays, as well as during the period of their creation, they form a methodological basis of the educational process in preschool educational institutions, general education schools and higher professional educational establishments for adults. It's time to draw parallels between the past and the present, to isolate and apply the ideas of $V$. O. Sukhomlynsky in order to preserve and multiply the heritage of the great master of the living word, the innovator of pedagogy and apply it widely within educational institutions of all levels, including continuous education throughout the life of specialists of all branches of science and production.

Key words: Nurse specialist, professional skills, professional education, postgraduate education, pedagogy, acmeology, teacher-innovator V. O. Sukhomlynsky. 